\title{
The Concept of Buraq in the Events of Isra' Mi'raj: Literature and Physics Perspective
}

\author{
Himatul Istiqomah', Muhammad Ihsan Sholeh ${ }^{2}$ \\ 1Universitas Negeri Malang, ${ }^{2}$ Universitas Negeri Jember \\ himastiq@gmail.com
}

\begin{abstract}
Isra' Mi'raj is one of the greatest phenomena that happened to the Prophet Muhammad PBUH after his beloved wife, Khadijah al-Kubra, passed away. It was told that when this event occurred, the Prophet Muhammad PBUH used Buraq during his journey from the Masjidil Haram, Makkah to the Masjidil Aqsha, Palestine, and when he ascended to Sidratul Muntaha. This research applied a descriptive qualitative method with a literature study. The results of this study indicate that there are two versions of the explanation about Buraq. From the literature's perspective, the Buraq is visualized as a riding animal in the form of a fourlegged animal that has high speed. This perspective is aimed at audiences from the non-academic community. Whereas,according to the physicist's perspective, Buraq is explained as a light which indeed has very high speed. This perspective is aimed at audiences from the academic community.
\end{abstract}

Keywords: Buraq; literature; physics

\section{Introduction}

Isra'and Mi'raj is one of the remarkable events that happened to the Prophet Muhammad PBUH when he was 50 years old. In his 10th prophetic year, this event is still considered impossible for those people who held stable rationality. Thus, it was easy to find people who believed that this event was just a false story or a hoax. Conversely, for those people who were free from the rationality, this event strengthened their belief in the prophet-hood and apostles of the Prophet Muhammad PBUH ${ }^{1}$.

In the discussion forum Building the Basic Concepts of Thinking guided by Dr. Christyaji ${ }^{2}$ during November 2019 that was held in the al-Manhal library, Landungsari Malang, the researchers obtained a description that there were three kinds of knowledge that the Universe bestowed upon humans. The first is historical knowledge. It is all knowledge that comes from the past,

\footnotetext{
${ }^{1}$ Himatul Istiqomah, Metamorfosa Kerasulan Muhammad SAW (Tinjauan Psikologi Sastra Pada Mawlidul Barzanji) (UIN Maliki Press, 2018), 100.

2FKIK, "Dosen," Fakultas Kedokteran dan Ilmu Kesehatan-UIN Maulana Malik Ibrahim Malang, 2020, http://fkik.uin-malang.ac.id/index.php/dosen/.
}

AJIS : Academic Journal of Islamic Studies, vol. 5, no. 1, 2020

IAIN Curup - Indonesia | ISSN 2580-3174, (p); 2580-3190 (e)

DOI: $10.29240 /$ ajis.v5i1.1373, page: 53-68 
which is no longer empirical. Knowledge in this category is better known as history. It prevails even for the knowledge that comes from the previous day, the previous hour, or just a previous moment. Thus, the way to respond to such knowledge is by thinking.

The second is theological knowledge. It is all knowledge that contains information about the future, which is not empirical at all. This knowledge is extremely related to human creed and belief. It depicts that every single thing that will happen in the next moment remains a mystery. Therefore, the way to deal with knowledge is to believe. However, the Universe has provided a repetition of signs or symptoms regularly, which can be recognized through the titen method, a method for being meticulous and painstaking.

The third is scientific knowledge. That is all empirical knowledge that is happening today, right now, and can be sensed. Thus, this knowledge is very limited in scope. However, scientific knowledge plays an important role in bridging between historical and theological knowledge. Through this scientific method, humans can recognize the repetition of natural phenomena that occurred in the past as a provision to predict what will happen in the future.

Through the above three knowledge categories, humans can determine their attitude towards much information that is found. Moreover, that knowledge help to determine the best way to convey the gotten information to the surrounding people.

The event of Isra' Mi'raj itself is included in the historical knowledge category since it happened centuries ago. Hence, the basic way to respond to it is by thinking. Furthermore, the next way is to process the gotten knowledge to be scientific knowledge until it can be ideas that are accepted by many people.

The previous study related to this present study mentioned that regarding semiotic studies, Isra' Mi'raj of the Prophet Muhammad PBUH and Gabrielare three signs that are related to each other. Furthermore, they form the integrity of meaning, as written in the story of the Mi'raj of the Prophet $(K M N)^{3}$.The event of Isra'Mi'raj was divided into eight sequences in the book Bainama Qishshah al-Mi'raj (BQM), where there were complete narrative and isotopic aspects ${ }^{4}$. Structurally, this event has a complete storyline even though

\footnotetext{
${ }^{3}$ Woko Gandung Anggoro and Penelitian, "Analisis Semiotik Naskah Kitab Mi'raj Nabi," Jurnal UNAIR, 2016, 89, http://journal.unair.ac.id.

"Iwan Marwan and Wildan Taufiq, "The Study of Narrative Semiotics in the Story of Isra Mi'Raj," Humanus 18, no. 1 (2019): 58, https://doi.org/10.24036/humanus.v18i1.104066.
} 
it does not include irony5. This event was adapted in al-Tawabi 'wa al-Zawabi' by IbnuShuhaid and Risalat al-Ghufran by Al-Ma'ari6and can be told through the development of special Audio media?.

The event of Isra'Mi'raj is recorded in three hadiths narrated by Anas bin Malik R.A. and continued by Bukhari in his Sahih. Although there is a difference in the text of the hadith (Matan), all of its essences guides people to take lessons from that event ${ }^{8}$. Furthermore, this event was also recorded in some Malay and Javanese manuscripts, ${ }^{9}$ and also,the event of Isra' Mi'raj is celebrated as an Islamic holiday, as happened in the Gorontalo community. ${ }^{10}$ Through Isra' Mi'raj events, Allah SWT commanded shalator pray as the main worship ${ }^{11}$. Moreover, this event contains educational values in the form of political, social, and spiritual values ${ }^{12}$, and it also contains character education, which is suitable for the millennial generation ${ }^{13}$.

By the event of Isra' Mi'raj, some previous studies scrutinized it not only from the social science aspect but also from using the scientific aspect. The result of this research showed that this event might be revealed by the

5Roro Fatikhin, “Qisah Al-Mi'raj Dalam Naskah Perpustakaan Masjid Agung Surakarta Dan Perpustakaan Nasional Republik Indonesia (Kajian Filologi Arab)," AlLahjah, 2018, 54.

6Rahmah Ahmad H Osman and Mohd Shahrizal Nasir, "Karya Al-Tawabi ‘ Wa Al-Zawabi ' Oleh Ibn Shuhayd ( 382-426H ) Dan Risalat Al-Ghufran Oleh Al-Ma 'Arri ( 363-449H ): Satu Adap Tasi Daripada Peristiwa Isra ' Mi ' Raj,” Dinika 8, no. 1 (2010): 1.

${ }^{7}$ Siti Umi Khasanah and Sulistiowati, "Pengembangan Media Audio 'Kisah Isra Mi'Raj Nabi Muhammad Saw' Pada Mata Pelajaran Sejarah Kebudayaan Islam Untuk Meningkatkan Hasil Belajar Siswa Kelas Iv Di Mi Ma'Arif Durung Banjar Candi Sidoarjo," Jurnal Mahasiswa Teknologi Pendidikan 5, no. 2 (2014): 1.

${ }^{8}$ Mohd Fariz bin Abdul Azziz, "Analisa Hadith Isra' Mi'raj Riwayat Anas Bin Malik r.a Di Dalam SHahih Bukhari," Academia, 3, accessed on January 31 st, 2020, https://www.academia.edu.

9Dick can der Meij, "Pluralism and Identity in the Indonesian-Malay World," Studia Islamika: Indonesian Journal for Islamic Studies 11, no. 3 (2004): 430.

${ }^{10}$ Ridwan Tohopi, "Tradisi Peraraan Isra' Mi'raj Dalam Budaya Islam Lokal

Masyarakat Gorontalo," El-Harakah 14, no. 1 (2012): 135, https://doi.org/10.18860/el.v0i0.2192.

${ }^{11}$ Abdul Haris, "Tafsir Tentang Peristiwa Isra' Mi'raj," TAJDID: Jurnal Ilmu Ushuluddin 14, no. 1 (2015): 167, https://doi.org/10.30631/tjd.v14i1.22.

12Muhammad Hidayat and Kalam Setia, "Nilai - Nilai Pendidikan Pada Peristiwa Isra Mi'raj," Fikiran Masyarakat 3, no. 2 (2015): 113.

${ }^{13 R i f q i}$ Muntaqo and Alfin Musfiah, "Tradisi Isra' Mi'raj Sebagai Upaya

Pembentukan Karakter Generasi Millenial," Jurnal Paramurobi 1, no. 2 (2018): 65. 
presence of super fluidal and warm holes theories. ${ }^{14}$ In respect of this finding, this event can be rationalized by using Einstein's theory of relativity ( $\mathrm{E}=$ mc2) ${ }^{15}$, Heisenberg's uncertainty theory ${ }^{16}$, or The Zero Kelvin's theory ${ }^{17}$.

Concerning the historical story of Isra' Mi'raj, there is an interesting part to be revealed. It is about the Buraq figure,which is known as a mount ofthe Prophet Muhammad PBUH. In some paintings painted by the artists in Cairo, the Buraq is visualized as an animal that is similar to a horse, fourlegged, human-headed and has a pair of wings ${ }^{18}$. In another way, Pratama and Sudrajat, in their research,stated that Buraq, which refers to a gleam,was also used as the theme design of a heart hospital in Surabaya. The speed of light existing inBuraq is described as the form of service and movement systems in that hospital.

Moreover,the architecture is designed by zoning and creating proper circulation to facilitatemobility. Also, the nature of the Buraq that provides security and comfort became the main attention to be realized in this hospital 19. In another place, the visualization of the Buraq as a winged horse, human-headed, and beautifully dressed by HaryadiSuadi became the most

${ }^{14}$ Trise Nurul Ain and Faris Ashari, "Isra' Mi'raj Dalam Kajian Al-Qur'an Dan Sains," Jurnal Inovasi Pendidikan Fisika Dan Integrasinya 01, no. 02 (2018): 34, http://e-journal.hikmahuniversity.ac.id/index.php/JIPFI/article/view/81.

${ }^{15}$ Fatoni Achmad and Ivonia, "Studi Analitis Peristiwa Isra' Mi'raj Nabi Muhammad SAW Dalam Pendekatan Sains," Momentum: Jurnal Sosial Dan Keagamaan 7, no. 1 (2018): 159, https://doi.org/10.29062/mmt.v7i2.22.

${ }^{16}$ Sri Jumini, “Teori Ketidakpastian Heisenberg Dalam Peristiwa Isro'Mi'roj," in Prosiding SNPS (Seminar Nasional Pendidikan Sains), vol. 3 (Surakarta: UNS, 2016), 467.

${ }^{17}$ Misbakhudin Misbakhudin, “Isra' Mi'raj Sebagai Mukjizat Akal (Upaya Memahami Qs. Al-Isra' Ayat 1)," Religia 15, no. 1 (2017): 120, https://doi.org/10.28918/religia.v15i1.120; Rahmati, "The Journey of Isra' and Mi'raj in Quran and Science Perspective," Ar Raniry, International Journal of Islamic Studies 4, no. 2 (2017): 323.

${ }^{18}$ Christiane Jacqueline Gruber, "The Prophet Muhammad's Ascension (Mi'raj) in Islamic Painting and Literature: Evidence from Cairo Collections," Bulletin of the American Research Center in Egypt 185 (2004): 27-29.

${ }^{19}$ Dimas Adi Pratama and Sudradjat, "Penerapan Tema Buraq Dalam Rancangan Rumah Sakit Jantung ( Surabaya Cardiac Center )," Jurnal Sains Dan Seni ITS 1, no. 1 (2012): $25 \& 27$. 
popular glass painting as the symbolic icon of Cirebon ${ }^{20}$. This imagination was even adapted in Javanese dance art, especially in Brebes, Central Java21.

Grounded to the explanation above, in this study, the researchers present two perspectives (from literature and physics) that are used to explain Buraq to society. The objective of this study is to achieve an alignment between those two perspectives and to prevent misunderstanding between the use of one method and another.

Research Methodology

The qualitative approach was used in this study to excavate the understanding of the studied object ${ }^{22}$. Furthermore, this is descriptive researchthat aims to describe what is contained in the studied text critically.

The primary source of data in this study is a story about the Buraqwritten in the book of NurudhDhalam by Sheikh Muhammad Nawawi AlSyafi'iy, which was compiled as a shari'a from nadhamAqidatul Awamby Ahmad Marzuqi's and published by Darulllm, Surabaya, ${ }^{23}$ Fann al- Qishshahby ZainilDahlanIsma'il which was published in DarulSayrqilJadid, Beirut, and the studied of Buraq in the book MetamorfosaKerasulan Muhammad SAW by HimatulIstiqomah ${ }^{24}$. Moreover, the secondary data sources were gotten from many books and research about Buraq, Isra'-Mi'raj, light theory, and other supporting data. The data collection is done by using library research methods.

\section{Buraq Text Story}

The following is the text of the story about buraq in the book of Nurudh Dhalam.

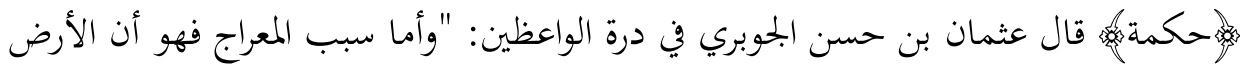

$$
\begin{aligned}
& \text { افتخرت على السماء فقالت الأرض: أنا خير منك لأنّ الله تعالى زينني بالبلاد والبحار والأهمار }
\end{aligned}
$$

${ }^{20}$ Rizal Sapari, “Interaksi Simbolik Dalam Tiga Lukisan Kaca Karya Haryadi Suadi," Jurnal Itenas Rekarupa 5, no. 2 (2019): 110.

${ }^{21}$ Triyanto Triyanto et al., "Brebes Buroq: The Art Expression of Coastal Javanese Moslem Society," Komunitas: International Journal of Indonesian Society and Culture 8, no. 1 (2016): 94, https://doi.org/10.15294/komunitas.v8i1.5266.

22Mahsun, Metode Penelitian Bahasa (Jakarta: Rajawali Press, 2014).

${ }^{23}$ Syekh Muhammad Nawawi Al-Syafi'iy, Nurudh Dhalam Syarh Nadham Aqidatul Awam Li Ahmad Marzuqi (Surabaya: Darul Ilm, 1936).

${ }^{24}$ Istiqomah, Metamorfosa Kerasulan Muhammad SAW (Tinjauan Psikologi Sastra Pada Mawlidul Barzanji). 


$$
\begin{aligned}
& \text { والأشجار والجبال وغيرها. فقالت السماء: أنا خير منك لأنّ الشمس والقمر والكواكب والأفلاك } \\
& \text { والبروج والعرش والكرمي والجنّة في. وقالت الأرض: في بيت يزوره ويطوف به الأنبياء والمرسلون } \\
& \text { والأولياء والمؤمنون عامّة. وقالت السماء: في البيت المعمور يطوف به مالائكة السموات وفي الجنّة } \\
& \text { التي هي مأوى أرواح الأنبياء والمرسلين وأرواحأولياء والصالحين. وقالت الأرض: إنّ سيّد المرسلين } \\
& \text { وخاتم النبيّين وحبيب ربّ العالمين وأفضل الموجودات عليه أكمل التحيّات وطن في وأجرى شريعته } \\
& \text { عليّ. فلمّا سمعت السماء هذا عجزت وسكنت على الجواب وتوجّهت إلى الله تعالى فقالت: إلهي } \\
& \text { أنت بجيب المضطرّ إذا دعاك وأنا عجزت عن جواب الأرض فأسألك أن يصعد محمّد إليّ فأتشرّف } \\
& \text { به كما تشرّفت الأرض بجماله وافتخرت25. }
\end{aligned}
$$

"(Hikmah) Uthman ibn Hasan al-Juwairi in his book, stated," Durrah alWa'idhin, "- Mi'raj is caused by the earth's pride over the sky.

Earth : "I'm better than you. Because Allah SWT decorates me with lands, oceans, rivers, trees, mountains, etc."

Sky : "I am better than you. Because I have sun, moon, planets, star clusters, and sura."

Earth : "I have a house where apostles, prophets, saints, and believers visit and perform tawaf."

Sky : "I have a BaitulMakmurwhere the angels perform tawaf. There is also a paradise in me where the spirits dwell for the prophets, apostles, saints, and pious people. "

Earth : "Verily the master of the apostles, the covering of the prophets, the beloved of the Lord of hosts, and the most important and perfect creation are in me. His teaching applies in my lap. "

After listening to the earth, the sky felt defeated and then be silent. Then he complained to God.

Sky : "O my Lord, You grant when someone asks you. I was defeated by the answers of the earth. Therefore, I ask you if Muhammad is raised to me. Thus, I will become as noble as it is, as the glory and pride of the earth because of its elegance. "

$$
\begin{aligned}
& \text { فأجاب دعوتما وأوحى الله تعالى إلى جبريل فقال: اذهب إلى الجنّة وخذ البراق واذهب إلى محمّد. فذهب } \\
& \text { جبريل ورأى أربعين ألف براق يرتعون في رياض الجنّة وعلى جبهتهم اسم محمّد ورأى فيهم براقا منكا رأسه وإسه }
\end{aligned}
$$

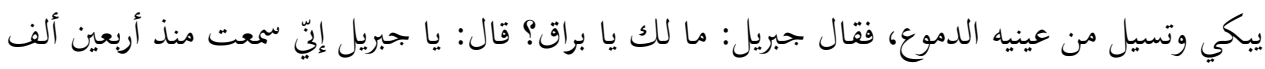

42.

25al-Syafi'iy, Nurudh Dhalam Syarh Nadham Aqidatul Awam Li Ahmad Marzuqi, 


$$
\begin{aligned}
& \text { سنة اسم محمّد فوقع في قلبي محبّة صاحب هذا لاسم وعشقته وبعد ذلك لم أحتجإلى طعام ولا شراب } \\
& \text { واحترقت بنار العشق. فقال جبريل: أنا أوصلك بمعشوقتك. تيمّ أخرجه وجاء به إلى النبيّ عليهولسلم } 26 .
\end{aligned}
$$

"Allah granted the wish of the sky while revealing to Gabriel," Go to heaven. Take the Buraq, then go to Muhammad!" Gabriel then left. Gabriel saw 40,000 Buraq on his forehead with the name Muhammad written in the gardens of paradise. Among them, Gabriel saw a Buraq whose head was sparkling bright, and tears were flowing.

Gabriel : "What's wrong with you, Buraq?"

Buraq : "O, Gabriel. Indeed, I have heard the name of Muhammad since 40,000 years ago. I fell in love with the owner of the name and always missed him. It made me don't need to eat or drink. I am burning in the fire of longing. "

Gabriel : "I will take you with to lover."

Gabriel then took the Buraq from heaven and brought it to the Prophet Muhammad PBUH. "

Resting upon the explanation above, Buraq is told as a resident ofheaven. Among 40.000 Buraq in the gardens of paradise, there was only one Buraq that was taken by Gabriel to meet the Prophet Muhammad PBUH. It is a Buraq who loves and misses him with only hearing his name without knowing him before. The great sincerity of love to the Prophet Muhammad PBUH then become a reality when Buraq was finally reunited with him.

\section{The Visualization of Buraq in The Literature}

The following is a visualization of the Buraq in the book of NurudhDhalam.

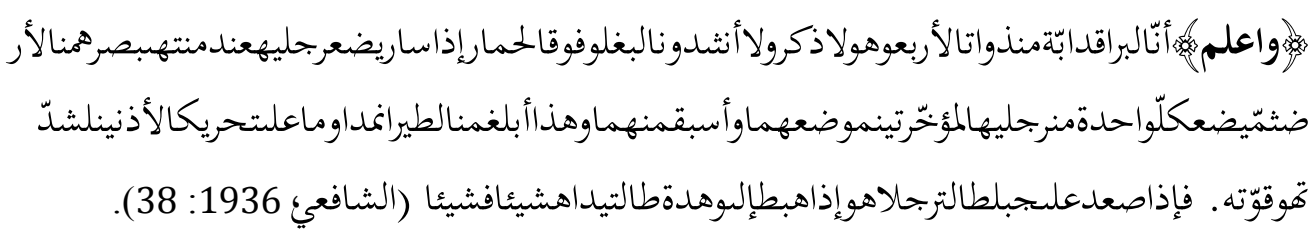

"(Know) that the Buraq is a four-legged animal. He is not male or female. He is not a donkey and is bigger than a horse. When walking, he set his two front legs at the edge of his view of the earth, while each of his rear legs became the foundation. He looks more like a bird that moves both ears to strengthen its speed. When he crossed the mountain, his hind legs stretched out. Whereas, when going down the cliff, the two front legs are stretching out slowly. " 


$$
\begin{aligned}
& \text { وهذه خصوصيّة لنبيّنا فلم تقع لنبيّ مّن ركبه قبله، وسمي براقا من البرق لشدّة سرعة سيره أومن }
\end{aligned}
$$

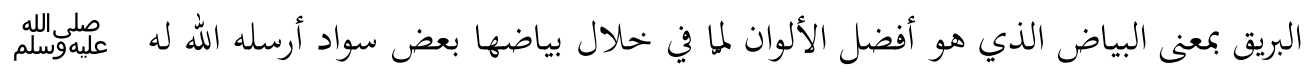

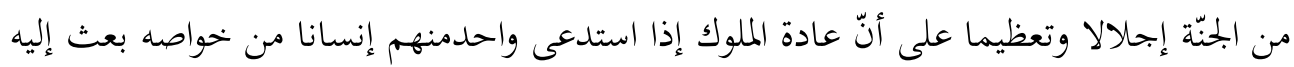



"This is special for our Prophet, which did not happen to previous Prophets. He is called Buraq from the term barq (lightning), due to the strength of speed its steps. Or from the term bariq (sparkle), which means white, known as the best color that Allah SWTsend fromheaven to light up the darkness as a form of exaltation and respect. It had been customary for the kings to call one of their own, he sent the best mounts to be used to attend his invitation. "

$$
\begin{aligned}
& \text { وأتاه البراق الأرفع، وهو دابة أبيض طويل فوق الحمار ودون البغال. يضع حافره عند منتهى طرفه }
\end{aligned}
$$

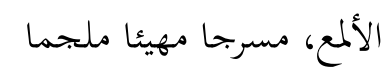

In the book Fann al-Qishshah, Buraq is also visualized as the animals that are similar to horses or white mules that have a high speed.

According to the data mentioned above, Buraq is visualized as a fourlegged animal, with very high speed. It was calledBuraq because of the pace of its steps that resembles lightning.

\section{Buraq in Physics}

In the origin of the word, Buraq lexically means lightning. In Physics, lightning is light that has such a high speed that it is difficult to perceive. Buraq in the Isra'event was later explained using the theory of Annihilation, a theory in Quantum Physics that explains the reaction of the formation of enormous energy due to collisions between matter and antimatter ${ }^{29}$.The annihilation reaction occurred when the mass of matter in the body of the Prophet Muhammad PBUH was erased by an antimatter mass inspired by Allah SWT through the Angel Gabriel, both of which collide and then disappear to form a new, greater energy known as Buraq, or in physics terms paired with gamma rays.

\footnotetext{
27 Al-Syafi'iy, 38.

28Zaini Dahlan Ismail, فنالقصة (Beirut: Dar el-Syarq el-Jadid, 1959), 108.

${ }^{29}$ Koesminarto, Fisika: Penerapannya Dalam Bidang Medis (Yogyakarta: UGM Press, 2007).
} 
As the concept of mass equality was formulated by Einstein, that matter under certain conditions can be turned into energy, and vice versa. Every tangible object in the Universe is composed of submicroscopic materials known as atoms, which are composed of protons, neutrons, and electrons, and every material has antimatter in it ${ }^{30}$.

This perspective shows that Buraq is not another subject that delivers the Prophet Muhammad PBUH in His Isra', but is part of himself. In other words, he runs Isra 'and Mi'raj with all his body, spirit, and soul ${ }^{31}$. This idea is as what is told in al-Barzanjiy:

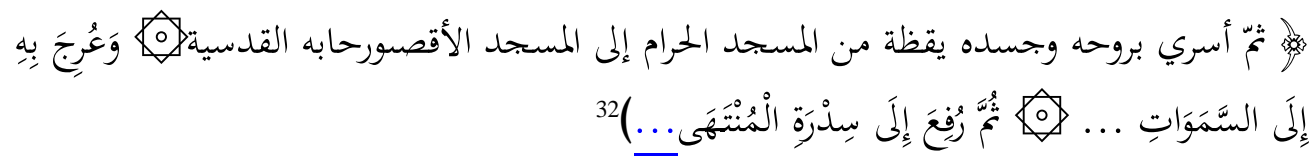

"Then He (Muhammad) was carried out with his spirit and body from the MasjidilHaram to the Masjidil Aqsa, which was accompanied by Gabriel. He was also raised (with his spirit and body) to the layers of the sky. Then, he was appointed to Sidratul Muntaha".

Because of the enormous speed of the Buraq, people around the Prophet Muhammad PBUH were unaware of the Isra-Mi'raj event. Therefore, this event is considered asa suprarational event ${ }^{33}$ which many infidels deny because it cannot be sensed ${ }^{34}$. However, believers canhave faith, believe, and justify the event as what Abu Bakr did until he obtained the title of al-Shiddiq ${ }^{35}$.



\section{${ }^{30}$ Koesminarto.}

${ }^{31}$ Aceng Zakaria, "Isra Mi'raj Sebagai Perjalanan Religi: Studi Analisis Peristiwa Isra Mi'raj Nabi Muhammad Menurut Al-Qur'an Dan Hadits," Al - Tadabbur: Jurnal Ilmu Al-Qur'an Dan Tafsir 4, no. 01 (2019): 100, https://doi.org/10.30868/at.v4i01.428.

32Ja'far bin Hasan Al-Barzanji, “مولد البرزنجي (نثر)", in (مولد البرزنجي, ed. Bassam Muhammad Barud (Abu Dhabi: Ishdarat al-Sahah al-Huzrajiyah, 2008), 118-19.

${ }^{33}$ Takdir Alisyahbana, "Paradigma Ilmu Pengetahuan Dan Iman Dalam Peristiwa Isro' Mi'raj Nabi Muhammad Saw," El-Ghiroh xiv, no. 1 (2018): 136, https://doi.org/10.1017/CB09781107415324.004.

${ }^{34}$ Khotimah Suryani, "Isra' Mi'raj Nabi Muhammad Saw Telaah Surat Al-Isra" Ayat 1)," in International Conference on Islamic Civilization Ans Society (ICICS), vol. 1 (Lamongan: UNISDA, 2017), 354, https://doi.org/10.1017/CB09781107415324.004.


البرزنجي ," Arabi: Journal of Arabic Studies, 1, 2 (2017): 127-40. 
"Glory to ((Allah)) Who did take His servant for a Journey by night from the Sacred Mosque to the Farthest Mosque, whose precincts We did bless,- so that We might show him some of Our Signs: for He is the One Who heareth and seeth (all things)." (QS. Al-Isra' verse 1)

As explained above, the Prophet Muhammad PBUH and Gabriel used the Buraq to take Isra'Mi'raj.Buraq lexically has the same meaning asword barqun(برق), which means lightning. Thus, Isra'or a journey from the MasjidilHaram to the MasjidilAqsa which has a distance of $1500 \mathrm{~km}$ or $15 \mathrm{x}$ $105 \mathrm{~m}$ can be reached within 0.005s by the Prophet Muhammad PBUHtogether with the Angel Gabriel by using Buraq (light) with a speed of $3 \times 10^{5} \mathrm{~km} / \mathrm{s}$ or $3 \mathrm{x}$ $10^{8} \mathrm{~m} / \mathrm{s}^{36}$.

Meanwhile, it is mentioned in verse abovethat the mileage of oil which should be achieved in $5 \times 10^{4}$ years can be reached only in some time overnight. If it is calculated mathematically using the speed formula in Physics, the following calculation will be obtained.

Known:

$\mathrm{s}=$ mileage of Mi'raj in meters, but in the Qur'an it is stated in time; $5 \times 10^{4}$

years. If it is made into seconds, $15,768 \times 10^{8}$ s (if 1 year $=365$ days) or

$158,112 \times 10^{7} \mathrm{~s}$ (if 1 year $=366$ days)

$\mathrm{v}=$ speed of light (buraq); $3 \times 10^{5} \mathrm{~km} / \mathrm{s}$ or $3 \times 10^{8} \mathrm{~m} / \mathrm{s}$

Asked:

t = time of Mi'raj; overnight ???

Answer:

To calculate the actual Mi'raj time, we can use a formula, $\mathrm{t}=\mathrm{s} / \mathrm{v}$

$t=15,768 \times 108: 3 \times 108$

$\mathrm{t}=\mathrm{s} / \mathrm{v}$

$\mathrm{t}=5256 \mathrm{~s}$ or 1.46 hours $\mathrm{t}=\mathrm{s} /$

$\mathrm{t}=158,112 \times 10^{7}: 3 \times 10^{8}$

$\mathrm{v}$

$t=5270.4$ s or 1,464 hours

Thus, the amount of time needed for the Prophet Muhammad PBUH to do Isra'i Miraj is 5256,005 s or 5270,405 s, about 1.5 hours less ${ }^{37}$,

${ }^{36}$ Sadiman Sadiman and Asri Karolina, "Pendekatan Saintific Quantum Dalam Memahami Perjalanan Isra' Nabi Muhammad SAW (Teori Saintifik Modulasi Quantum Isra')," FOKUS: Jurnal Kajian Keislaman Dan Kemasyarakatan 2, no. 2 (2017): 219, https://doi.org/10.29240/jf.v2i2.326.

37The results of this calculation are to revise the researchers' previous writing in the book Metamorfosa Kerasulan Muhammad Saw (2018. Malang: UIN Maliki Press). There is a mistake in the final result because of missing one zero (0). 
$\mathrm{t}_{\mathrm{t}}=\mathrm{ti}+\mathrm{tm}$

$\mathrm{t}_{\mathrm{t}}=0.005 \mathrm{~s}+5256 \mathrm{~s}$

$t_{t}=5256,005 \mathrm{~s}$ or 1.46

hours $\mathrm{t}_{\mathrm{t}}=\mathrm{ti}+\mathrm{tm}$

$\mathrm{t}_{\mathrm{t}}=0.005 \mathrm{~s}+5270.4 \mathrm{~s}$

$t_{t}=5270,405$ s or 1,464 hours

Information:

$\mathrm{t}_{\mathrm{i}} \quad=$ time needed by the Prophet Muhammad PBUH for Isra '.

$\mathrm{t}_{\mathrm{m}} \quad=$ time taken by Prophet Muhammad PBUH for Mi'raj.

$t_{\mathrm{t}}=$ total time needed by Prophet Muhammad PBUH for Isra 'and Mi'raj.

In a paper presented by researchers in the Scientific Halaqah agenda at Luhur Malang High Boarding School, Yuda wrote that the annihilation reaction was classified as a reversible reaction. Through the reaction of materialization, the enormous energy can be broken down again to form matter and antimatter that originally collided ${ }^{38}$. Based on this information, after the event ofIsra'Mi'rajProphet Muhammad PBUH can return to normal, a real figure that can be sensed. Thus, after the events of Isra'Mi'raj, he could be gathered with his people as usual.

The writer, in his discussion with Dr. Christyaji, assumes that the Prophet Muhammad PBUH probably did Isra'Mi'raj more than once. He can do it repeatedly after knowing the route to go and go home that can be taken only with superfast time.

\section{The Explanation of Buraqin Writer Perspective}

The explanation of Buraq is as what was written in the text of the Buraq story by Sheikh Muhammad Nawawi Al-Shafi'iy and ZainiDahlan Ismail. Through this visualization, it was illustrated as if the Buraq could be seen clearly in people's imagination who listen to the story. This method is very appropriate to be applied inpublic, especially for non-academic people. It is becauseit will be easier for them to receive information that hassimilarities to the empirical things they encounter in everyday life. However, the conveyance is imbued with some different and noble values. Thus, the story of Isra'Mi'raj becomes so meaningful and valuable.

Such an explanation is usually found in elementary and secondary schools as well as in some traditional boarding schools. As witnesses and actors of history, researchers acknowledge that this method is more easily

38Himatul Istiqomah, “Teori Anihilasi,” Halaqah Ilmiah, 2015. 
accepted by the laities, especially by the children due to theirsimple and limited mindset.

\section{The Explanation of Buraqin Physicist Perspective}

As what is exemplified in annihilation theory, through the embodiment of Buraq as a light, the event of Isra' Mi'raj can be more rationally accepted. The calculations with mathematical formulas in Physics above are also very helpful in draining the imagination.

Such explanations are usually found at the higher level of education. Therefore, there were only a few people who were able to accept an ideaand knowledge from this perspective. Thus,the knowledge in thisperspective cannot be applied or generalized to the public but rather to certain academic people.

\section{Conclusion}

In the event of Isra' Mi'raj, there is an interesting object for researchers, namely Buraq. As regards this object, researchers found two areas of study about the Buraq. They are fromthe literature perspective and physics perspective (the perspective of writer and physicists).In the writer's view, based on the literature, the Buraqis illustrated in a story with its special uniqueness. This explanation is appropriate for the general public, especially non-academic people.Whereas, inthe physicists' view, the Buraq is illustrated in annihilation theory, which is then formulated mathematically. This explanation is more appropriate to the academic people.

Grounded in above findings, it can be concluded that both the first and second perspectives are the ways to process historical knowledge scientifically. As a result, it becomes scientific knowledge that can be understood and accepted by the audiences following their respective capacities.

\section{References}

Achmad, Fatoni, and Ivonia. "Studi Analitis Peristiwa Isra' Mi'raj Nabi Muhammad SAW Dalam Pendekatan Sains." Momentum: Jurnal Sosial Dan Keagamaan 7, no. 1 (2018): 159-84. https://doi.org/10.29062/mmt.v7i2.22.

Ain, Trise Nurul, and Faris Ashari. “Isra' Mi'raj Dalam Kajian Al-Qur'an Dan Sains." Jurnal Inovasi Pendidikan Fisika Dan Integrasinya 01, no. 02 (2018): 29-34. http://ejournal.hikmahuniversity.ac.id/index.php/JIPFI/article/view/81. 
H Istiqomah, M I Sholeh: The Concept of Buraq in the Events of Isra' Mi'raj | 65

Al-Barzanji, Ja'far bin Hasan. "مولد البرزنجي (نثر)) مولد البرزنجي, edited by Bassam Muhammad Barud. Abu Dhabi: Ishdarat al-Sahah al-Huzrajiyah, 2008.

Al-Syafi'iy, Syekh Muhammad Nawawi. Nurudh Dhalam Syarh Nadham Aqidatul Awam Li Ahmad Marzuqi. Surabaya: Darul Ilm, 1936.

Alisyahbana, Takdir. "Paradigma Ilmu Pengetahuan Dan Iman Dalam Peristiwa Isro' Mi'raj Nabi Muhammad Saw." El-Ghiroh xiv, no. 1 (2018): 117-37. https://doi.org/10.1017/CB09781107415324.004.

Anggoro, Woko Gandung, and Penelitian. "Analisis Semiotik Naskah Kitab Mi'raj Nabi." Jurnal UNAIR, 2016, 84-90. http://journal.unair.ac.id.

Azziz, Mohd Fariz bin Abdul. "Analisa Hadith Isra' Mi'raj Riwayat Anas Bin Malik r.a Di Dalam SHahih Bukhari." Academia. Accessed January 31, 2020. https://www.academia.edu.

Dick can der Meij. "Pluralism and Identity in the Indonesian-Malay World." Studia Islamika: Indonesian Journal for Islamic Studies 11, no. 3 (2004): 430-66.

Fatikhin, Roro. “Qisah Al-Mi'raj Dalam Naskah Perpustakaan Masjid Agung Surakarta Dan Perpustakaan Nasional Republik Indonesia (Kajian Filologi Arab)." Al-Lahjah, 2018, 41-56.

FKIK. "Dosen." Fakultas Kedokteran dan Ilmu Kesehatan-UIN Maulana Malik Ibrahim Malang, 2020. http://fkik.uin-malang.ac.id/index.php/dosen/.

Gruber, Christiane Jacqueline. "The Prophet Muhammad's Ascension (Mi'raj) in Islamic Painting and Literature: Evidence from Cairo Collections." Bulletin of the American Research Center in Egypt 185 (2004): 24-31.

Haris, Abdul. "Tafsir Tentang Peristiwa Isra' Mi'raj." TAJDID: Jurnal Ilmu Ushuluddin $14, \quad$ no. 1 (2015): 167-80. https://doi.org/10.30631/tjd.v14i1.22.

Hidayat, Muhammad, and Kalam Setia. "Nilai - Nilai Pendidikan Pada Peristiwa Isra Mi'raj.” Fikiran Masyarakat 3, no. 2 (2015): 113-32.

Ismail, Zaini Dakhlan. فن القصة. Beirut: Dar el-Syarq el-Jadid, 1959.

Istiqomah, Himatul. Metamorfosa Kerasulan Muhammad SAW (Tinjauan Psikologi Sastra Pada Mawlidul Barzanji). UIN Maliki Press, 2018.

———. "Teori Anihilasi." Halaqah Ilmiah, 2015. 
Istiqomah, Himatul, and Halimi. " اتجاهات كون النبي و الرسول في شخصية محمد في نثر مولد الد .البرزنجي." Arabi: Journal of Arabic Studies, 1, 2 (2017): 127-40.

Jumini, Sri. “Teori Ketidakpastian Heisenberg Dalam Peristiwa Isro'Mi'roj.” In Prosiding SNPS (Seminar Nasional Pendidikan Sains), 3:467-78. Surakarta: UNS, 2016.

Khasanah, Siti Umi, and Sulistiowati. "Pengembangan Media Audio 'Kisah Isra Mi'Raj Nabi Muhammad Saw' Pada Mata Pelajaran Sejarah Kebudayaan Islam Untuk Meningkatkan Hasil Belajar Siswa Kelas Iv Di Mi Ma'Arif Durung Banjar Candi Sidoarjo." Jurnal Mahasiswa Teknologi Pendidikan 5, no. 2 (2014): 1-8.

Koesminarto. Fisika: Penerapannya Dalam Bidang Medis. Yogyakarta: UGM Press, 2007.

Mahsun. Metode Penelitian Bahasa. Jakarta: Rajawali Press, 2014.

Marwan, Iwan, and Wildan Taufiq. "The Study of Narrative Semiotics in the Story of Isra Mi'Raj." Humanus 18, no. 1 (2019): 58-67. https://doi.org/10.24036/humanus.v18i1.104066.

Misbakhudin, Misbakhudin. "Isra' Mi'raj Sebagai Mukjizat Akal (Upaya Memahami Qs. Al-Isra' Ayat 1).” Religia 15, no. 1 (2017): 14-26. https://doi.org/10.28918/religia.v15i1.120.

Muntaqo, Rifqi, and Alfin Musfiah. “Tradisi Isra' Mi'raj Sebagai Upaya Pembentukan Karakter Generasi Millenial." Jurnal Paramurobi 1, no. 2 (2018): 65-78.

Osman, Rahmah Ahmad H, and Mohd Shahrizal Nasir. "Karya Al-Tawabi ' Wa Al-Zawabi ' Oleh Ibn Shuhayd ( 382-426H ) Dan Risalat Al-Ghufran Oleh Al-Ma 'Arri ( 363-449H ): Satu Adap Tasi Daripada Peristiwa Isra ' Mi ‘ Raj." Dinika 8, no. 1 (2010): 1-17.

Pratama, Dimas Adi, and Sudradjat. "Penerapan Tema Buraq Dalam Rancangan Rumah Sakit Jantung ( Surabaya Cardiac Center )." Jurnal Sains Dan Seni ITS 1, no. 1 (2012): 24-27.

Rahmati. "The Journey of Isra' and Mi'raj in Quran and Science Perspective." Ar Raniry, International Journal of Islamic Studies 4, no. 2 (2017): 323-36.

Sadiman, Sadiman, and Asri Karolina. "Pendekatan Saintific Quantum Dalam Memahami Perjalanan Isra' Nabi Muhammad SAW (Teori Saintifik Modulasi Quantum Isra')." FOKUS: Jurnal Kajian Keislaman Dan Kemasyarakatan 2, no. 2 (2017): 200-225. 
H Istiqomah, M I Sholeh: The Concept of Buraq in the Events of Isra' Mi'raj | 67

https://doi.org/10.29240/jf.v2i2.326.

Sapari, Rizal. "Interaksi Simbolik Dalam Tiga Lukisan Kaca Karya Haryadi Suadi." Jurnal Itenas Rekarupa 5, no. 2 (2019): 107-14.

Suryani, Khotimah. "Isra' Mi'raj Nabi Muhammad Saw Telaah Surat Al-Isra" Ayat 1)." In International Conference on Islamic Civilization Ans Society (ICICS), 1:344-55. Lamongan: UNISDA, 2017. https://doi.org/10.1017/CB09781107415324.004.

Tohopi, Ridwan. 'Tradisi Peraraan Isra' Mi'raj Dalam Budaya Islam Lokal Masyarakat Gorontalo." El-Harakah 14, no. 1 (2012): 135-55. https://doi.org/10.18860/el.v0i0.2192.

Triyanto, Triyanto, Nur Rokhmat, Mujiyono Mujiyono, and Eko Sugiarto. "Brebes Buroq: The Art Expression of Coastal Javanese Moslem Society." Komunitas: International Journal of Indonesian Society and Culture 8, no. 1 (2016): 94-101. https://doi.org/10.15294/komunitas.v8i1.5266.

Zakaria, Aceng. "Isra Mi'raj Sebagai Perjalanan Religi: Studi Analisis Peristiwa Isra Mi'raj Nabi Muhammad Menurut Al-Qur'an Dan Hadits." Al Tadabbur: Jurnal Ilmu Al-Qur'an Dan Tafsir 4, no. 01 (2019): 99-112. https://doi.org/10.30868/at.v4i01.428. 
68 | AJIS : Academic Journal of Islamic Studies, vol. 5, no. 1, 2020 